\title{
MTOR wt Allele
}

National Cancer Institute

\section{Source}

National Cancer Institute. MTOR wt Allele. NCI Thesaurus. Code C51054.

Human MT OR wild-type allele is located in the vicinity of 1 p36.2 and is approximately 156 $\mathrm{kb}$ in length. This allele, which encodes serine/threonine-protein kinase mTOR protein, is involved in translational control and the regulation of ribosome biogenesis. The MTOR gene is associated with polycystic kidney disease. 